\title{
Helicobacter pylori infection and its association with anemia among adult dyspeptic patients attending Butajira Hospital, Ethiopia
}

\author{
Dargaze Kibru', Baye Gelaw², Agersew Alemu ${ }^{3}$ and Zelalem Addis ${ }^{3 *}$
}

\begin{abstract}
Background: Helicobacter pylori infection is associated with anemia. Understanding the magnitude of H.pylori infection and its association with anemia is important in the management of anemic patients. The aim of this study was to assess the association between H.pylori infection and anemia among dyspeptic patients.

Methods: A cross-sectional study was conducted in Butajira Hospital, Southern Ethiopia among 401 systematically dyspeptic patients. A structured questionnaire was used to collected data about the patient characteristics. Blood samples were analyzed for red blood cell parameters. Stool samples were assessed for the presence of H.pylori antigens and the presence of intestinal helminthes. Data were summarized in frequencies (\%) and mean (SD) as appropriate. Chi-square test, logistic regression and independent t-tests were used in the analysis as needed. In all cases P-value $<0.05$ was considered as statistically significant.

Results: The overall prevalence of $H$. pylori infection was $52.4 \%$ and it was significantly associated with age, presence of intestinal parasites, smoking habit, alcohol drinking habit and body mass index. The prevalence of anemia among H.pylori infected patients $(30.9 \%)$ was significantly $(P<0.001)$ higher than uninfected patients (22.5\%). The mean (SD) values of HGB, MCV, MCH, MCHC, HCT and RBC count was significantly different between H.pylori infected and uninfected patients.

Conclusion: This study showed high prevalence of H.pylori infection among dyspeptic patients and this was associated with age and some behavioral characteristics of the patients. H.pylori infected patients showed high rate of anemia prevalence as compared to their H.pylori unifected counter parts. From this study it can be recommended that intervention activities related to the behavioral characteristics and prevention of intestinal parasitic infections should be in place. The cross sectional nature of the study has a limitation to show cause and effect associations and hence association between H.pylori infections with anemia need to be investigated in cohort type studies.
\end{abstract}

Keywords: Anemia, Butajira, Dyspepeptic, H.pylori

\section{Background}

Helicobacter pylori infection has been recognized as one of the most common chronic bacterial infections in humans and infecting more than half of the population of the world. The overall prevalence is high in developing countries [1]. H. pylori infection is a worldwide problem but the prevalence varies from country to country $[1,2]$. H. pylori infection is acquired in early childhood and

\footnotetext{
*Correspondence: zelalemaddis@ymail.com

${ }^{3}$ Deapartment of Medical Mlcrobiology, School of Biomedical and Laboratory Sciences, University of Gondar, P.O. Box 196, Gondar, Ethiopia

Full list of author information is available at the end of the article
}

becomes a chronic infection if left untreated [3]. The majority of infected people remain asymptomatic, and only small portions develop illness, usually in adulthood [4]. H. pylori cause upper gastrointestinal disease such as gastritis, peptic ulcer disease and also increase the risk of gastric cancer [5,6]. Male gender, increasing age, shorter height, tobacco use, lower socioeconomic status, obesity, and lower educational status of the parents in studies conducted among children are proposed risk factors for infection [7].

Several studies suggested an association between $H$. pylori infection with iron deficiency and anemia $[8,9]$. 
H. pylori infection and extra gastric manifestations, pernicious anemia (10) and idiopathic thrombocytopenic purpura have been reported [10,11]. Active H. pylori infection was independently associated with iron deficiency and iron-deficiency anemia [12,13] and presence of $H$. pylori infection is associated with a poorer response to oral iron therapy [14]. It has been suggested that eradication of $H$. pylori may result in improvement of anemia even without iron supplementation $[14,15]$.

It is hypothesized that $H$. pylori-associated with anemia is caused by both compromised absorption of bio-available iron in the context of hypochlorhydria [16], and the competing iron demands of $H$. pylori and the host $[17,18]$. Most dietary iron is in the non-hemic ferric form, and an acidic intra-gastric $\mathrm{pH}$ is needed to reduce it to the ferrous form for absorption. This reaction is promoted by gastric acidity and ascorbic acid, which is thus considered the most potent regulator of iron absorption [19]. H. pylori a major cause of chronic superficial gastritis leading to atrophy of gastric glands and leading to decreased gastric acid secretion [20]. H. pylori need iron to thrive and it possesses a $19-\mathrm{kDa}$ iron-binding protein resembling ferritin, that may play a role in storage of excessive iron by the bacteria [21]. Moreover, since these bacteria have a high turnover rate, a large amount of iron may be lost in stools in the form of dead bacteria [22]. H. pylori has been found more frequently in dyspeptic patients [23]. The aim of the current study was to investigate the relation between H. pylori infection and anemia among dyspeptic patients attending medical care at Butajira Hospital.

\section{Methods}

\section{Study area}

The study was conducted at Butajira hospital which is found in Butajira town, Gurage Zone, Southern Nations Nationalities, and People's Region (SNNPR) located $135 \mathrm{~km}$ from the capital-city, Addis Ababa. The town lies on the average at $2,100 \mathrm{~m}$ above the sea level. Butajira hospital is a zonal hospital with 110 beds that gives health service for peoples living in Butajira and the surrounding rural kebeles. The hospital report shows that it gives health service for an average of about 250 patients per day at the outpatient department. The hospital catchment area population is estimated around 1.3 million.

\section{Study design and period}

A cross-sectional prospective study was conducted from April to Jun 2013.

\section{Sample size and sampling technique}

The sample size was determined by using single population proportion formula taking $53 \%$ prevalence of $H$. pylori infection among dyspeptic patients [24] and a marginal error of $5 \%$. Accordingly the sample size was determined 382 but we also considered a $5 \%$ non-response rate so that the final sample size was 401.

Study subjects were included using systematic random sampling technique. In Butajira hospital an average of 18 dyspeptic patients attend the outpatient clinic each day. The total expected dyspeptic patients during the study period were estimated 792 . When the total population was divided by the sample size, the sample interval was found 2 and every two dyspeptic patient were selected until a total of 401 samples obtained.

All adult (age $\geq 18$ years) patients presented with dyspepsia complaint were included in the study. Among those patients who were voluntary to participate in the study, those who had any surgery and blood donation, previous stomach or small bowel surgery, those who took treatment for $H$. pylori within the last three month, and pregnant women excluded. The patients were excluded, due to any of the exclusion criteria, from the study following critical review of their medical charts.

\section{Data collection and laboratory methods General characteristics of the study participants}

A structured questionnaire was used to collect data on demographic (sex, age, monthly income, marital status, educational status), behavioral (smoking, alcohol intake, dietary habit) and physical (body mass index) characteristics of the study participants. BMI $\leq 18.5 \mathrm{~kg} / \mathrm{m}^{2}$ was classified as underweight; $\mathrm{BMI}=18.6-24.9 \mathrm{~kg} / \mathrm{m}^{2}$ as normal weight; $\mathrm{BMI}=25-29.9 \mathrm{~kg} / \mathrm{m}^{2}$ as overweight; and $\mathrm{BMI} \geq 30 \mathrm{~kg} / \mathrm{m}^{2}$ as obese [25].

\section{Sample collection and analysis}

About $3 \mathrm{ml}$ of venous blood was collected and examined for hematological parameters using Sysmex K-21 hematology analyzer. Approximately three gram of stool sample was collected in a clean screw cupped plastic container and checked for the presence of $H$. pylori antigen using H. pylori Rapid Test Strip (Creative Diagnostics.). Portion of the stool sample was used to assess the presence of intestinal helminthes using formol ether concentration technique as per a standard procedure [26].

\section{Data analysis and interpretation}

Data were entered and analyzed using SPSS version 16.0. Continuous variables were summarized using means $( \pm$ SD) and categorical variables were summarized in frequencies (percentages). Association between the prevalence of anemia and H.pylori infection was assessed by $\mathrm{X}^{2}$ tests. Anemia was defined according to the WHO definition as a hemoglobin concentration of $<12 \mathrm{~g} / \mathrm{dL}$ in women, $<13 \mathrm{~g} / \mathrm{dL}$ in men [27]. The difference in the mean values of RBC parameters between H.pylori positive and negative individuals was explored using independent 
sample T-test. Logistic regression was used to determine the effect of independent variables on the prevalence of H.pylori infection. In all case a $95 \%$ confidence interval was used and P-values less than 0.05 were considered as statistically significant.

\section{Ethical consideration}

The study was commenced after ethically approved by the ethical review committee of the School of Biomedical and Laboratory Science, University of Gondar. Permission to conduct the study was also obtained from the hospital administration. Written informed consent was obtained from each study participant and the results were kept confidential. Any result that was necessary for the patient was communicated with the physician for appropriate management.

\section{Results}

Sociodemographic, behavioral and physical characteristics of the study participants

A total of 401 adult dyspeptic patients (148 males and 253 females) with a mean $( \pm$ SD) age of $37.3( \pm 13.7)$ years participated in this study. Majority of them were rural residents $(70 \%)$, married (72.8\%), and illiterate (56.9\%). The mean $( \pm \mathrm{SD})$ body mass index of the study population was $20.4( \pm 2.3) \mathrm{kg} / \mathrm{m}^{2}$. During the time of data collection about $4.5 \%$ and $10.7 \%$ of the study participants had a habit of cigarette smoking and drinking alcohol respectively. An assessment on the food habits of the study participants revealed that $8.7 \%, 63.8 \%$ and $33.4 \%$ had a habit of eating meat, vegetables and eggs 1-3 days/ week respectively. Intestinal parasites were identified in $30.7 \%$ of the study participants (Table 1 ).

\section{Prevalence of H.pylori infection and associated risk factors} The overall prevalence of $H$. pylori infection was $52.4 \%$ $(\mathrm{n}=210) ; 66.7 \%(\mathrm{n}=140)$ in females and $33.3 \%(\mathrm{n}=70)$ in males. The relative frequency of the infection was higher in the age group 39-48 (50.6\%) and among urban dwellers (54.4\%). Among the different characteristics of the study participants'; age, presence of intestinal parasites, smoking habit, alcohol drinking habit and BMI showed statistically significant association with H.pylori infection (Table 2).

\section{Prevalence of anemia and its association with H.pylori infection}

Prevalence of anemia among dyspeptic patient was $26.9 \%$ $(\mathrm{n}=108) ; 64.8 \%$ in females and $35.2 \%$ in males. The mean $( \pm$ SD) hemoglobin concentration was $13.2( \pm 1.4) \mathrm{g} / \mathrm{dl}$ and $14.1( \pm 1.5) \mathrm{g} / \mathrm{dl}$ in females and males respectively. The prevalence of anemia among H.pylori infected patients was $30.9 \%$ and $22.5 \%$ among uninfected patients. The difference in the prevalence of anemia between H.pylori infected and uninfected patients was statistically significant $\left(\mathrm{X}_{2}=26.8 ; \mathrm{P}<0.001\right)$ (Table 3$)$. The mean (SD) of other parameters related to red blood cell were also compared between H.pylori infected and uninfected patients. Accordingly statistically significant differences were observed in $\mathrm{HGB}, \mathrm{MCV}, \mathrm{MCH}, \mathrm{MCHC}, \mathrm{HCT}$ and number of RBC (Table 4).

\section{Discussion}

In this study, the prevalence of $H$. pylori infection among patients with dyspeptic symptoms was $52.37 \%$. This prevalence is relatively lower than other reports conducted in different parts of African and Asia continent, which reported a prevalence ranging from $67 \%$ up to $86.8 \%$ [28-31]. The prevalence of $H$ pylori varies greatly among countries and among population groups within the same country [2]. However, our finding is relatively similar with previous reports made in Ethiopia 53\% [24] and Kuwait 49.7\% [32]. Lack of clear cut definition of dyspepsia, H. pylori diagnostic method, sample size, social and economic factors could be some of the possible reasons for these variations.

The results of the current study also showed slight difference in prevalence of $H$. pylori infection between females and males (55.3\% vs $47.3 \%$ respectively), but the difference was not statistically significant $(P=0.12)$. This finding goes in contrary to previous reports that indicated females were at significant risk to have for $H$. pylori infection $(24,32,33)$. However, our findings agree with other studies that showed the rate of $H$. pylori infection is independent of gender $[31,24,30]$.

We found correlation between age and H. pylori infection being the prevalence was higher in older age groups $(\mathrm{P}<0.001)$. This finding is in accordance with the results of former studies made in Kuwait [32] South Africa [33] and Ethiopia [30]. Moreover, study conducted in Addis Ababa, Ethiopia, showed a peak prevalence of $H$. pylori infection among older patients, within the age group between 54-61 years [24]. The most probable reason is that infection by $H$. pylori can be acquired in earlier age and persist throughout the life time of the patient and may cause disease at older age. However, there are also reports that showed higher prevalence of $H$. pylori infection during the younger age. For example, study conducted in Iran showed patient at younger age were more affected [31] and in Nigeria the peak prevalence of $H$. pylori infection was found among patients within the age group between 20-39 years old [29].

The current study result also showed a significant negative association betteween alcohol consumption and H. pylori infection (AOR 0.37; 95\%; CI 0.17-0.82, $\mathrm{P}=0.014$ ). This result contradicts with previous report from Gondar, Ethiopia [30] and South Africa [33] that showed a positive association between $H$. pylori infection 
Table 1 Sociodemographic, behavioral and physical characteristics of the study participants

\begin{tabular}{|c|c|}
\hline Characteristics & Frequenc) \\
\hline \multicolumn{2}{|l|}{ Sex } \\
\hline Female & $253(63 \%)$ \\
\hline Male & $148(37 \%)$ \\
\hline \multicolumn{2}{|l|}{ Age } \\
\hline $18-28$ & $130(32.4 \%)$ \\
\hline 29-38 & $93(23.2)$ \\
\hline $39-48$ & 79(19.7) \\
\hline $49-58$ & $66(16.5)$ \\
\hline $59-68$ & $33(8.2)$ \\
\hline \multicolumn{2}{|l|}{ Residence } \\
\hline Urban & $120(30)$ \\
\hline Rural & $281(70)$ \\
\hline \multicolumn{2}{|l|}{ Family income/month ETB } \\
\hline$<776$ & $271(67.6 \%)$ \\
\hline$\geq 776$ & $130(32.4 \%)$ \\
\hline \multicolumn{2}{|l|}{ Marital status } \\
\hline Married & 292(72.8) \\
\hline Single & $72(18)$ \\
\hline Widowed/divorced & $37(9.2)$ \\
\hline \multicolumn{2}{|l|}{ Educational status } \\
\hline Never attend school & $228(56.9)$ \\
\hline Primary school & $92(22.9)$ \\
\hline Secondary school and above & $81(20.2)$ \\
\hline \multicolumn{2}{|l|}{ BMI $\left(\mathrm{kg} / \mathrm{m}^{2}\right)$} \\
\hline Undernourished & $75(18.7)$ \\
\hline Normal & $315(78.6)$ \\
\hline Overweight & $11(2.7)$ \\
\hline \multicolumn{2}{|l|}{ No of people in household } \\
\hline$<5$ & 298(74.3) \\
\hline$>6$ & $103(25.7)$ \\
\hline \multicolumn{2}{|l|}{ Cigarette smoking } \\
\hline Yes & $18(4.5)$ \\
\hline No & $383(95.5)$ \\
\hline \multicolumn{2}{|l|}{ Alcohol drink } \\
\hline Yes & $43(10.7)$ \\
\hline No & 358(89.3) \\
\hline \multicolumn{2}{|l|}{ Meat consumption per week } \\
\hline Not at all & $366(91.3)$ \\
\hline$>1-3$ & $35(8.7)$ \\
\hline \multicolumn{2}{|l|}{ Egg consumption per week } \\
\hline Not at all & $267(66.6$ \\
\hline$>1-3$ & 134(33.4) \\
\hline
\end{tabular}

Table 1 Sociodemographic, behavioral and physical characteristics of the study participants (Continued)

\begin{tabular}{ll}
\hline Vegetable consumption/week & \\
Not at all & $20(5)$ \\
$1-3$ & $256(63.8)$ \\
$>4$ & $125(31.2)$ \\
Intestinal parasite & \\
Negative & $278(69.3)$ \\
Positive & $123(30.7)$ \\
\hline
\end{tabular}

and alcohol consumption. In those studies it was reported that alcohol consumption could be a risk factor for $H$. pylori infection. Nevertheless, there are also reports that documented a non statistical risk reduction of $H$. pylori infection upon alcohol consumption [34]. Besides, the type and amount of alcohol had also an effect on the association. However, basic microbiology tells us that alcohol is known to have direct antimicrobial effects. Therefore, the lower prevalence of $H$. pylori infection among patients that consumed alcohol compared with the nonalcoholics attracted us to support the hypothesis that alcohol intake may have preventive effect for $H$. pylori infection.

In this study cigarette smoking was significantly associated with $H$. pylori infection $(\mathrm{P}=0.01)$. Unlike other studies that reported no significant association with current smoking or any other measure of using tobacco [34]. Others proposed that smoking appears to affect treatment success [35]. These contradictory results may be due to uncontrolled confounding factors such as social class or differential antibiotic use.

Intestinal parasitic infection in this study was significantly associated with $H$. pylori infection $(\mathrm{p}=0.009)$. This is different from a finding from Australia [36]. Intestinal parasitic infections and elevated IgE levels were associated with a reduced $H$. pylori prevalence in adults, living in Mexico, suggesting that intestinal parasites could affect persistence of $H$. pylori [37]. The presence of association in our study may be due to poor hygienic status that favors high rate of parasitic infection and similar route of transmission shared by H.pylori. But the real mechanism of interaction needs to be investigated with cohort studies.

There are quite a number of studies in the literature demonstrated the relationship between $H$. pylori infection and anemia. In the current study, the prevalence of anemia among $H$. pylori positive patients $(\mathrm{n}=65,30.95 \%)$ was significantly higher $(\mathrm{P}=0.05)$ than $H$.pylori negative patients $(n=43 ; 22.5 \%)$. But other studies from Latin American countries showed no association [38] while a study from Haiti showed an inverse association [39]. The 
Table 2 Bivariate and multivariate analysis of patient characteristics with $\boldsymbol{H}$. pylori infection

\begin{tabular}{|c|c|c|c|c|c|c|}
\hline \multirow[t]{2}{*}{ Risk factors } & \multicolumn{2}{|c|}{ H.pylori status } & \multirow[t]{2}{*}{ COR $(95 \% \mathrm{Cl})$} & \multirow[t]{2}{*}{ P-value } & \multirow[t]{2}{*}{ AOR(95\%Cl) } & \multirow[t]{2}{*}{ P-value } \\
\hline & $+\mathrm{ve}$ & -ve & & & & \\
\hline \multicolumn{7}{|l|}{ Age category } \\
\hline $18-28$ & 47 & 83 & 1 & & 1 & \\
\hline $29-38$ & 44 & 49 & $1.58(0.92-2.72)$ & .095 & $1.37(0.77-2.45)$ & .277 \\
\hline $39-48$ & 40 & 39 & $1.81(1.03-3.20)$ & .040 & $1.74(0.95-3.17)$ & .070 \\
\hline $49-58$ & 49 & 17 & $5.09(2.64-9.82)$ & .000 & $5.18(2.58-10.42)$ & .000 \\
\hline $59-68$ & 30 & 3 & $17.66(5.11-60.2)$ & .000 & $17.63(4.95-62.7)$ & .000 \\
\hline \multicolumn{7}{|c|}{ Intestinal helminthes } \\
\hline Negative & 132 & 146 & 1 & & 1 & \\
\hline Positive & 78 & 45 & $1.92(1.24-2.96)$ & .003 & $1.9(1.17-3.07)$ & .009 \\
\hline \multicolumn{7}{|l|}{ Smoking } \\
\hline Yes & 16 & 2 & 7.89(1.77-34.36) & .007 & $8.36(1.68-41.64)$ & \\
\hline No & 194 & 189 & 1 & & 1 & \\
\hline \multicolumn{7}{|l|}{ Alcohol drink } \\
\hline Yes & 18 & 25 & $0.62(0.33-1.18)$ & .15 & $0.37(0.17-0.82)$ & .014 \\
\hline No & 192 & 166 & 1 & & 1 & \\
\hline \multicolumn{7}{|l|}{ BMI category } \\
\hline Undernourished & 53 & 22 & $2.00(0.55-7.27)$ & 0.28 & $3.16(0.75-13.39)$ & .119 \\
\hline Normal & 151 & 164 & $0.77(0.23-2.56)$ & 0.67 & $1.10(0.28-4.29)$ & .889 \\
\hline Overweight & 6 & 5 & 1 & & 1 & \\
\hline \multicolumn{7}{|l|}{ Anemia } \\
\hline Anemic & 50 & 58 & $0.637(0.38-1.04)$ & 0.072 & $1.58(0.96-2.61)$ & 0.072 \\
\hline Non anemic & 160 & 133 & 1 & & 1 & \\
\hline
\end{tabular}

association observed in our study was also reflected on other RBC parameters as determined using $t$-test. We found that $H$. pylori stool antigen positive patients have significantly lower hemoglobin and hematocrit levels than $H$. pylori negative patients $(13.3 \mathrm{~g} / \mathrm{dl}$ versus $13.8 \mathrm{~g} / \mathrm{dl}$, $\mathrm{P}=0.001)$ and $(41.9 \%$ versus $43.3 \%, \mathrm{P}=0.009)$ respectively. Similar observation was reported from Turkish among teenager [40]. However, findings are not in agreement with the reports made by Fraser et al [41] and Kermati et al [42] where no association between H. pylori infection and Hgb/HCT levels was reported. Moreover, there was statistically significant difference in $\mathrm{MCHC}(\mathrm{P}=0.002)$ and $\mathrm{MCH}(\mathrm{P}=0.003)$ values between $\mathrm{H}$. pylori stool antigen positive and negative dyspeptic patients, indicating the impact of $H$. pylori infection on hematological parameters.

Table 3 Association between H.pylori sero-status and anemia prevalence among dyspeptic patients

\begin{tabular}{llll}
\hline & $\begin{array}{l}\text { H.pylori } \\
\text { sero-positive }\end{array}$ & $\begin{array}{l}\text { H.pylori } \\
\text { sero-negative }\end{array}$ & $\begin{array}{l}\boldsymbol{X} \mathbf{2} \\
(\boldsymbol{P} \text {-value })\end{array}$ \\
\hline Anemic & $65(30.95)$ & $43(22.5)$ & $3.62(0.05)$ \\
Non anemic & $145(69.01)$ & $148(77.5)$ & \\
\hline
\end{tabular}

Limitations of the study

This study was conducted on dyspeptic patients who have had many underline disease conditions as a confounding factors that could not fully controlled so that it might have impact on the outcome of the statistical correlations between $H$. pylori infection, anemia and other variables of interest. The cross sectional nature of the study was also another limitation to show cause and effect relationship between the variables.

Table 4 Association between RBC indices with H.pylori infection

\begin{tabular}{llll}
\hline Parameter & \multicolumn{2}{l}{ Mean (SD) } & P-value $(\mathbf{9 5 \%}$ Cl) \\
\cline { 2 - 3 } & H.pylori positive & H.pyori negative & \\
\hline HGB & $13.3(1.3)$ & $13.8(1.6)$ & $0.001(0.19,0.77)$ \\
MCV(fl) & $87.5(7.2)$ & $88.9(7.3)$ & $0.058(-0.048,2.79)$ \\
MCH & $27.85(2.54)$ & $28.65(2.78)$ & $0.003(0.28,1.33)$ \\
MCHC (pg) & $31.35(2.03)$ & $32(2.33)$ & $0.002(0.26,1.12)$ \\
RBCX10 $/ \mu \mathrm{l}$ & $4.63(0.59)$ & $4.8(0.72)$ & $0.01(0.04,0.29)$ \\
HCT $(\%)$ & $41.9(5.3)$ & $43.3(5.9)$ & $0.009(0.38,2.58)$ \\
\hline
\end{tabular}

$\mathrm{HGB}=$ hemoglobin; $\mathrm{MCV}=$ mean corpuscular volume; $\mathrm{MCH}=$ mean corpuscular hemoglobin; $\mathrm{MCHC}=$ mean corpuscular hemoglobin concentration; $\mathrm{RBC}=$ red blood cell; $\mathrm{HCT}=$ hematocrit. 


\section{Conclusion}

This study indicated that the prevalence of $H$. pylori infection was high among dyspeptic patients in the study area. The rate of $\mathrm{H}$. pylori infection was also increasing in advancing age showing that age is one of the risk factors in acquiring the infection. Moreover, cigarette smoking, and intestinal helmintic infection were identified as risk factors for $H$. pylori infection too. Alcohol consumption habit in our study was negatively associated with $H$. pylori infection. Mean hematological parameters and RBC were significantly reduced among $H$. pylori positive patients compared. This study indicated the need for further large scale study to determine the possible risk factors for such high rate of infection. Moreover cohort type studies are recommended to formulate a cause and effect relationship between the risk factors and H.pylori sero-positivity.

\section{Competing interests}

The authors declare that they have no competing interests.

\section{Authors' contributions}

This work was carried out in collaboration between all authors. Author DK designed the study, wrote the protocol, and wrote the first draft of the manuscript. Author BG commented the protocol and analyze the data. Author AA managed the literature search and involved in data analysis. Author ZA participated in data analysis and prepare the final manuscript for publication. All authors read and approved the final manuscript.

\section{Acknowledgment}

We would like to acknowledge all study participants who were volunteers to give samples and respond to questionnaires. Our special thanks go to Butajira hospital administration for their unreserved support during the data collection.

\section{Author details}

${ }^{1}$ Butajira Zonal Hospital, Southern Nations, Nationalities and Peoples Region, Butajira, South Ethiopia. ${ }^{2}$ Department of Medical Microbiology, School of Biomedical and Laboratory Sciences, University of Gondar, Gondar, Ethiopia. ${ }^{3}$ Deapartment of Medical Mlcrobiology, School of Biomedical and Laboratory Sciences, University of Gondar, P.O. Box 196, Gondar, Ethiopia.

Received: 18 August 2014 Accepted: 24 November 2014 Published online: 09 December 2014

\section{References}

1. Hunt RH, Xiao SD, Megraud F, Leon-Barua R, Bazzoli F, van der Merwe $S$, Vaz Coelho LG, Fock M, Fedail S, Cohen H, Malfertheiner P, Vakil N, Hamid S, Gohl KL, Wong BC, Krabshuis J, Le Mair A: World Gasteroenterology Organization Global Guide line: Helicobacter pylori in Developing Countries. World Gasteroenerology Organization, 2010. http://www.world gastroenterology.org/assets/downloads/en/pdf/guidelines/11_helicobacter_ pylori_developing countries en.pdf

2. Suerbaum S, Michetti P: Helicobacter pylori infection. N Engl J Med 2002, 347:1175-1186.

3. Torres J, Perez-Perez G, Goodman KJ, Atherton JC, Gold BD, Harris PR, La Garza AM, Guarner J, Muñoz O: A comprehensive review of the natural history of Helicobacter pylori infection in children. Arch Med Res 2000, 31:431-469.

4. Cover TL, Blaser MJ: Helicobacter pylori in health and disease. Gastroenterology 2009, 136:1863-1873.

5. Egan $\mathrm{BJ}, \mathrm{O}^{\prime} \mathrm{C}$ onnor $\mathrm{HJ}$, Morain CAO: What is new in the management of Helicobacter pylori? Ir J Med Sci 2008, 177:185-188.

6. Malfertheiner P, Megraud F, O'Morain C, Bazzoli F, El-Omar E, Graham D, Hunt R, Rokkas T, Vakil N, Kuipers EJ: Current concepts in the management of Helicobacter pylori infection: the Maastricht III Consensus Report. Gut 2007, 56:772-781.
7. Ford AC, Axon ATR: Epidemiology of Helicobacter pylori infection and Public Health Implications. Helicobacter 2010, 15:1-6.

8. Qu XH, Huang XL, Xiong P, Zhu CY, Huang YL, Lu LG, Sun X, Rong L, Zhong L, Sun DY, Lin H, Cai MC, Chen ZW, Hu B, Wu LM, Jiang YB, Yan WL: Does Helicobacter pylori infection play a role in iron deficiency anemia? A metaanalysis. World J Gastroenterol 2010, 16:886-896.

9. Muhsen K, Cohen D: Helicobacter pylori infection and iron stores: a systematic review and meta-analysis. Helicobacter 2008, 13:323-340.

10. Sarari AS, Farraj MA, Hamoudi W, Essawi TA: Helicobacter pylori, a causative agent of vitamin B12 deficiency. J Infect Dev Countries 2008, 2:346-349.

11. Stasi R, Sarpatwari A, Segal JB, Osborn J, Evangelista ML, Cooper N, Provan D, Newland A, Amadori S, Bussel JB: Effects of eradication of Helicobacter pylori infection in patients with immune thrombocytopenic purpura: a systematic review. Blood 2009, 113:1231-1240.

12. Baggett HC, Parkinson AJ, Muth PT, Gold BD, Gessner BD: Endemic iron deficiency associated with helicobacter pylori infection among school-aged children in Alaska. Pediatrics 2006, 117:396-404.

13. Ashorn M, Ruuska T, Makipenaa A: Helicobacter pylori infection and iron deficiency anemia in children. Scand J Gastroenterol 2001, 36:701-705.

14. Valiyaveettil AN, Hamide A, Bobby Z, Krishnan R: Effect of anti-Helicobacter pylori therapy on outcome of iron-deficiency anemia: a randomized, controlled study. Indian J Gastroenterol 2005, 24:155-157.

15. Malik R, Guleria K, Kaur I, Sikka M, Radhakrishnan G: Effect of Helicobacter pylori eradication therapy in iron deficiency anaemia of pregnancy - A pilot study. Indian J Med Res 2011, 134:224-231.

16. Harris PR, Serrano CA, Villagrán A, Walker MM, Thomson M, Duarte I, Windle HJ, Crabtree JE: Helicobacter pylori-associated hypochlorhydria in children, and development of iron deficiency. J Clin Pathol 2013, 66:343-347.

17. Shaw JG, Friedman JF: Iron deficiency anemia: focus on infectious diseases in lesser developed countries. Anemia 2011:1-10. http://www.hindawi.com/journals/anemia/2011/260380/

18. Annibale B, Capurso G, Lahner E, Passi S, Ricci R, Maggio F, Delle FG: Concomitant alterations in intragastric $\mathrm{pH}$ and ascorbic acid concentration in patients with Helicobacter pylori gastritis and associated iron deficiency anaemia. Gut 2003, 52:496-501.

19. Conrad ME, Umbreit JN: Iron absorption and transport-an update. Am J Hematol 2000, 64:287-298.

20. Lacy BE, Rosemore J: Helicobacter pylori: ulcers and more: the beginning of an Era;symposium. J Nutr 2001, 131:2789-2793.

21. Doig P, Austin JW, Trust TJ: The Helicobacter pylori 19.6-kilodalton protein is an iron-containing protein resembling ferritin. J Bacteriol 1993, 61:2694-2697.

22. Seo JK, Ko JS, Choi KD: Serum ferritin and Helicobacter pylori infection in children: a sero-epidemiologic study in Korea. J Gastroenterol Hepatol 2002, 17:754-757.

23. Kandulski A, Venerito M, Malfertheiner S: Therapeutic strategies for the treatment of dyspepsia. Expert Opin Pharmaco Ther 2010, 11:2517-2525.

24. Taddesse G, Habteselassie A, Desta K, Esayas S, Bane A: Association of dyspepsia symptoms and Helicobacter pylori infections in private higher clinic, Addis Ababa, Ethiopia. Ethiop Med J 2011, 49:109-116.

25. Kuczmarski RJ, Ogden CL, Grummer-Strawn LM, Flegal KM, Guo SS, Wei R, Curtin LR, Roche AF, Johnson CL: CDC growth charts for the United States: methods and development. Vital Health Stat 2002, 11:1-190.

26. Cheesbrough M: District Laboratory Practice in Tropical Countries Part I. 2nd edition. New York: Cambrige University Press; 2006.

27. WHO: Iron Deficiency Anaemia: As -sessment, Prevention and Control. A Guide for Programme Managers. Geneva, Switzerland: WHO; 2001.

28. Hashemi MR, Rahnavardi M, Bikdeli B, Zahedani MD: H. pylori infection among 1000 southern Iranian dyspeptic Patients. World J Gastroenterol 2006, 12:5479-5482.

29. Mustapha S, Pindiga U, Yusuph H, Goni B, Jibrin Y: Helicobacter pylori infection among dyspeptic patients at a tertiary hospital in Northern Nigeria. Int J Infect Dis 2011, 9:42-48.

30. Moges F, Kassu A, Mengistu G, Adugna S, Andualem B, Nishikawa T, Ota F: Seroprevalence of Helicobacter pylori in dyspeptic patients and its relationship with HIV infection, $A B O$ blood groups and life style in a university hospital, Northwest Ethiopia. World J Gastroenterol 2006, 12:1957-1961. 
31. Shokrzadeh L, Baghaei K, Yamaoka Y, Shiota S, Mirsattari D, Porhoseingholi A, Zali MR: Prevalence of Helicobacter pylori infection in dyspeptic patients in Iran. Gastroenterol Insights 2012, 4:24-27.

32. Alazmi WM, Siddique I, Alateeqi N, Al-Nakib B: Prevalence of Helicobacter pylori infection among new outpatients with dyspepsia in Kuwait. BMC Gastroenterol 2010, 10:1-4.

33. Tanih NF, Okeleye BI, Ndip LM, Clarke AM, Naidoo N, Mkwetshana N, Green E, Ndip RN: Helicobacter pylori prevalence in dyspeptic patients in the Eastern Cape province - race and disease status. S Afr Med J 2010, 100:734-737.

34. Hishida A, Matsuo K, Goto Y, Naito M, Wakai K, Tajima K, Hamajima N: Smoking behavior and risk of helicobacter pylori infection, gastric atrophy and gastric cancer in Japanese. Asian Pac J Cancer Prev 2010, 11:313-317

35. Suzuki T, Matsuo K, Ito H, Sawaki A, Hirose K, Wakai K, Sato S, Nakamura T, Yamao K, Ueda R, Tajima K: Smoking increases the treatment failure for helicobacter pylori eradication. Am J Med 2006, 119:217-224.

36. Cherian S, Forbes D, Sanfilippo F, Cook A, Burgner D: Helicobacter pylori, helminth infections and growth: a cross-sectional study in a high prevalence population. Acta Paediatr 2009, 95:860-864.

37. Torres J, Perez GP, Ximenez C, Muñoz L, Camorlinga-Ponce M, Ramos F, Gomez A, Muñoz O: The association of intestinal parasitosis and H. Pylori infection in children and adults from a Mexican community with high prevalence of parasitosis. Helicobacter 2003, 8:179-185.

38. Santos IS, Boccio J, Davidsson L, Hernandez-Triana M, Huanca-Sardinas E, Janjetic M, Moya-Camarena SY, Paez-Valery MC, Ruiz-Alvarez V, Valencia ME, Valle NCJ, Vargas-Pinto G, Solano L, Thomas J: Helicobacter pylori is not associated with anaemia in Latin America: results from Argentina, Brazil, Bolivia, Cuba, Mexico and Venezuela. Public Health Nutr 2009, 12:1862-1870.

39. Shak JR, Sodikoff JB, Speckman RA, Rollin FG, Chery MP, Cole CR, Suchdev PS: Anemia and Helicobacter pylori seroreactivity in a rural Haitian population. Am J Trop Med Hyg 2011, 85:913-918.

40. Süoglu OD, Gökçe S, Saglam AT, Sökücü S, Saner G: Association of Helicobacter pylori infection with gastroduodenal disease, epidemiologic factors and iron-deficiency anemia in Turkish children undergoing endoscopy, and impact on growth. Pediatr Int 2007, 49:858-863.

41. Fraser AG, Scragg R, Schaaf D, Metcalf P, Grant CC: Helicobacter pylori infection and iron deficiency in teenage females in New Zealand. N Z Med J 2010, 123:38-45.

42. Kermati MR, Siadat Z, Mahmoudi M: The correlation between $\mathrm{H}$ pylori infection with serum ferritin concentration and iron deficiency anemia. Int J Hematol Oncol 2007, 17:16-20.

\section{doi:10.1186/s12879-014-0656-3}

Cite this article as: Kibru et al: Helicobacter pylori infection and its association with anemia among adult dyspeptic patients attending Butajira Hospital, Ethiopia. BMC Infectious Diseases 2014 14:656.

\section{Submit your next manuscript to BioMed Central and take full advantage of:}

- Convenient online submission

- Thorough peer review

- No space constraints or color figure charges

- Immediate publication on acceptance

- Inclusion in PubMed, CAS, Scopus and Google Scholar

- Research which is freely available for redistribution 